\title{
'LET'S SEE IF IT WON'T GO AWAY BY ITSELF.' LGBT MICROAGGRESSIONS AMONG TEACHERS IN SOUTH AFRICA
}

\author{
Dennis A Francis \\ Stellenbosch University \\ E-mail: dafrancis@sun.ac.za
}

\section{Finn Reygan}

University of the Witwatersrand

E-mail: finncgreygan@gmail.com

\section{ABSTRACT}

We explored types and qualities of microaggressions or subtle forms of discrimination towards lesbian, gay, bisexual and transgender (LGBT) people among teachers in South Africa. For data collection, we used in-depth interviews. Twenty-five Life Orientation teachers, nine men and 16 women, from both rural and urban schools throughout the Free State Province participated. Our findings suggest heterosexism as well as subtle and sometimes harder to pin down forms of bias - microaggressions $\square$ are experienced in these contexts. Given the educational policy shifts on LGBT rights in South Africa, we argue that microaggressions need to be clearly located in the larger macro context of systemic heterosexism which pervades schools and the teaching of sexuality education in South Africa. We conclude with implications for teaching and support interventions to make schools more LGBT inclusive.

Keywords: microaggressions; heterosexism, homophobia; LGBT; schools; teachers; South Africa

\section{UNISA}

Education as Change

Volume 20 | Number 3 | 2016 | pp. 180-201

www.educationaschange.co.za
DOI: http://dx.doi.org/10.17159/1947-9417/2016/1124 Print ISSN 1682-3206 | Online 1947-9417

(C) 2016 The Author(s) 


\section{INTRODUCTION}

Microaggressions may be understood as -

...brief and commonplace daily verbal, behavioural, or environmental indignities, whether intentional or unintentional, that communicate hostile, derogatory, or negative slights and insults towards members of oppressed groups. (Nadal 2008, 23)

The research on microaggressions originally focused on race-based microaggressions and emerged from the Critical Race Theory literature (see Lynn 2002; Solórzano, Ceja \& Yosso 2000; Solórzano \& Yosso 2002; Yosso 2002; Yosso 2005) and has only in very recent years explored microaggressions in relation to sexual and gender minorities (see Nadal et al. 2011; Nadal, Rivera \& Corpus 2010; Sue \& Capodilupo 2008). As Nadal et al. (2011) point out, the research indicates that LGBT people, and particularly LGBT young people experiencing oppression, may also be a target of microaggressions. Hill and Willoughby (2005) and Walls (2008) argue that bias against LGBT people has become more subtle and less direct, thereby continuing to perpetuate heterosexism and gender normativity while excluding LGBT people. Nadal, Rivera and Corpus (2010) suggest a theoretical taxonomy of LGBT-related microaggressions that includes: the use of heterosexist and transphobic language; the perpetuation of heteronormative and gender normative behaviours and cultures; the presumption of universal LGBT experience; the exoticisation of LGBT identities, bodies and lives; the outright disrespect, discomfort and disapproval of LGBT lives; the denial of heterosexism and homophobia; and the pathologising of LGBT people. Microaggressions also become 'contested microaggressions' when the target of a microaggression protests about the aggressing act and the 'microaggressor' denies intentionality or responsibility (MinikelLacocque 2013).

Microaggressions appear in diverse settings, including schools. Exploring the subtle and complex ways in which heterosexism and 'Othering' are reproduced and normalised has the potential to reveal what needs to be addressed in creating equitable and inclusive schools. We explored the ways in which South African teachers perpetuated subtle forms of heterosexism or microaggressions against LGBT people in their education provisioning. Two questions guide our article - what do microaggressions among teachers in South Africa look like and how are these microaggressions embedded in teacher narratives? In answering these questions, we first present a discussion of Kumashiro's (2000; 2002) anti-oppressive framework locating microaggressions in the larger macro context of systemic heterosexism which pervades schools and the teaching of sexuality education in South Africa. Next is an overview of research methods used in our study. The third part examines the data of interviews with 25 teachers. The paper concludes by noting implications for teaching and support interventions to make schools more LGBT inclusive. 


\section{TROUBLING MICROAGRESSIONS IN EDUCATION}

Kumashiro $(2002,31)$ outlines four ways to conceptualise and challenge oppression: education for the Other, education about the Other, education that is critical of privileging and Othering, and education that changes students and society. Education for the Other is premised on improving the experiences of learners who are in some way Othered or oppressed, such as LGBT students. Education about the Other focuses on curriculum and what all students (both privileged and not) know and should know about the Other. Education that is critical of privileging and Othering maintains that it is important to know not just how some groups are Othered and oppressed but also how certain groups are privileged as well as how this dual process is legitimised and maintained. Finally, there is an education that changes students and society through curricular and pedagogical reforms and which explores the complexities of anti-oppressive education through developing concepts such as resistance, partiality, crisis and unknowability in terms of teaching and learning.

The work of Kumashiro $(2000 ; 2002)$ focuses on the ways in which certain groups are systemically privileged and disadvantaged, and on ways to effect change in society. Combining the work of Kumashiro with the phenomenon of microaggressions functions to bridge the gap between the individual and the institutional, elucidating the way in which these two levels are mutually reinforcing. The work of Kumashiro also speaks directly to the perpetuation of the 'hidden curriculum' in a cross-generational and cross-cultural manner including contexts as varied as South Africa (see Francis 2017; Kumashiro, Baber, Richardson, Ricker-Wilson \& Wong 2004). In South Africa this is an important consideration given historical legacies and the ways in which oppression operates not just at the macro, social, intergroup level but also at the individual, psychological and intrapsychic levels. Microaggressions, therefore, need to be clearly located in the larger macro context of systemic heterosexism which pervades schools and the teaching of sexuality education in South Africa (DePalma \& Francis 2014b; Francis 2012; 2017; Francis \& Reygan 2016; Reygan \& Francis 2015). Exploring what happens at the 'micro' level through the notion of microagressions provides a useful framework for understanding the kind of change that needs to take place in the classroom and schools.

South Africa has a long history of institutionalised racism and continues to grapple with its postcolonial legacy. Since the transition in the early 1990s from apartheid state to functioning democracy, divisions and fault lines have remained. This is despite the fact that the South African Constitution was the first in the world to include sexual orientation protections, where same-sex marriage has been legal since 2006, where policy is generally, though not always, inclusive (Thani 2016), and where there are thriving LGBT communities (Bennett \& Reddy 2015; Matabeni 2011; 2014; Reid 2003; Reid \& Dirsuweit 2002). At the same time violence, discrimination, marginalisation and exclusion continue to characterise the lives of many LGBT people (Bennett \& Reddy 2015; Butler \& Astbury 2008; Kowen \& Davis 2006; Matabeni 2011; 2014; McArthur 2015; Msibi 2012; Reid 2003; Reid \& Dirsuweit 2002). 
In South Africa the Apartheid regime promoted and maintained Christian values and severely policed sexuality, introducing 'social and moral hygiene' in sex education which was coupled with Christian teachings on the sinfulness of sex outside marriage (Marx 2014; Posel 2004; Reid 2003). In more recent times there has been ongoing and intense resistance to new forms of sex education including from schools, religious bodies and NGOs. For example, a number of studies point to ongoing beliefs among some teachers that sexuality education is a moral and values-related topic (Baxen 2008; DePalma \& Francis 2014a; Francis 2016a; Francis \& DePalma 2013; Helleve, Flisher, Onya, Mukoma \& Klepp 2009) and that it does not belong in the classroom (Ahmed, Flisher, Mathews, Mukoma \& Jansen 2009; Francis 2010; Helleve et al. 2009; Mathews, Boon, Flisher \& Schaalma 2007; Wood \& Rolleri 2014). Helleve et al. (2009) and Francis $(2012 ; 2013)$ also found that teachers, afraid of being seen to break with tradition, feel under pressure to teach values akin to those of the local community. Microaggressions are likely occurring beyond teachers' conscious awareness and are therefore detrimentally impacting on their ability to teach in an inclusive and affirming manner. Here the concepts of internalised oppression and internalised domination (see Blumenfeld 2000; Francis \& Msibi 2011; Griffin, D'errico, Harro \& Schiff 2007; Hardiman, Jackson \& Griffin 2007; Pharr 1998; Pheterson 1986; Young 2000) are relevant. Internalised oppression is the acceptance and incorporation by individuals belonging to oppressed groups of the prejudices of dominant society against them. More especially, internalised domination is the acceptance and incorporation by dominant group members of prejudices against others. This includes feelings of self-righteousness, superiority and normalcy along with feelings of fear and guilt, projections and denial of reality. Internalised domination - in this case heterosexism - makes it less likely that teachers will accept the reality of heterosexist-related prejudice and discrimination in classrooms. It will lead teachers to normalise heterosexuality to the point that they may be less likely to teach in an inclusive and affirming manner about sexual and gender diversity.

\section{RESEARCH METHOD}

Our study draws on a broader project that included in-depth interviews with 25 South African Life Orientation teachers in schools in the Free State, South Africa (see DePalma \& Francis 2014a; 2014b; 2014c; Francis \& DePalma 2013; 2015; Reygan \& Francis 2015). The Free State is South Africa's third largest province and the history of the province, like much of the country, can be characterised as one of exclusion, land appropriation, oppression and forced removals of peoples (Free State's Regional Steering Committee 2010, 1). The Free State finds itself at midpoint among the nine provinces of South Africa in terms of development indicators and has a higher unemployment rate than the rest of the country $(28.6 \%$ compared with $24.6 \%)$ with just over $42 \%$ of the population living in poverty. There are significant racial and 
gender inequalities including in employment, with unemployment among Africans much higher than among whites (32.4\% compared to $9.9 \%$ ) and unemployment among women higher than among men (32\% compared with $25.6 \%$ ). In short, the province may be understood as a place of missed opportunities in the new dispensation (Free State's Regional Steering Committee 2010, 11).

Participants were a convenience sample of nine men and 16 women who came from both rural and urban schools throughout the Free State. We employed purposeful sampling to recruit participants and teachers were identified through our network of teachers who teach Life Orientation. ${ }^{1}$ Once these teachers had been contacted and interviewed they identified others and so our sample snowballed. Teachers were considered eligible for participation if they had been teaching Life Orientation for at least one year.

In terms of race, 11 participants self-identified as African, 11 as white and 3 as coloured. We use this racialised terminology, established under the Apartheid regime, because it continues to be socially relevant and does reflect economic, educational and cultural differences (Unterhalter, Epstein, Morrell \& Moletsane 2004). All participants were Afrikaans or Sesotho first-language speakers and spoke English as a second language. ${ }^{2}$ Sometimes participants switched to speak in Sesotho and Afrikaans and the transcripts were translated accordingly. All 25 participants received a print copy of their interview transcription for review. So as to provide a social identity context for the reader, we have used pseudonyms followed by a descriptor of racial and gender identity and the school at which the teacher taught (See TABLE 1). For example, AW (WF38-UT/S/ST) should read that AW is a 38-year-old white female teaching at an urban township (UT) or suburban school (S) or a small town (ST).

We utilised in-depth interviews with broad questions to enable teachers to speak openly about their approach to and teaching of sexual diversity. Interviews were conducted in English by the first author and a white woman born in the USA. Interviews were audiotaped, transcribed and checked for accuracy against the original recordings. At the root of in-depth interviewing is an interest in understanding people's experience and their meaning of that experience. In-depth interviewing assumes that meanings, understandings, and interpretations cannot be standardised and, therefore, cannot be obtained with a formal, fixed choice questionnaire (Denzin 1989, 42-43). The in-depth interviews ranged from 60 to 90 minutes and were conducted in the teachers' classrooms, school offices or at a seminar room at the university.

Ethical approval for the study was granted by the Ethics Committee at the University of the Free State. Informed consent was obtained from each of the participants prior to the interview and the confidentiality of both participants and their schools was assured through the use of pseudonyms.

1 Life Orientation is a course that develops young people's personal, social, physical and psychological health and well-being and aims to teach them how to be civic-minded and engaged citizens.

2 Participants in the study spoke English as a second language and so we decided therefore to edit the quotes presented in our study so as to make them more accessible and readable. 
The data were thematically analysed as outlined by Merriam (1998). Analysing data 'involves consolidating, reducing, and interpreting what people have said and what the researcher has seen and read - it is the process of making meaning' (Merriam 1998, 178). Informed by the literature on microaggressions we initially did a close reading of the data looking not only for overt and clearly articulated forms of heterosexism but also at subtler, covert and hidden forms of discrimination and bias towards LGBT people. We proceeded to see if this was similar to other participants' narratives and if it was we developed this as a broad new theme across the data set. Peer debriefing between the authors was used to minimise potential bias and we present examples of each of these themes below with supporting verbatim extracts from participants' reports.

\section{FINDINGS}

A number of themes emerged from our analysis of the data. These were: subtle heterosexism, heteronormativity and pathology, discomfort and disapproval of LGBT lives, and 'culture'/religion. Given the manner in which the teachers are constructed in our study, we are cautious and want to avoid casting blame on teachers in South Africa. Life Orientation (LO) teachers have received little or no training in the area of gender and sexuality diversity. The literature abounds on pre-service and in-service teacher education as insufficient and teachers have not been provided with adequate opportunity to engage reflexively with these issues (Bhana 2012; Francis 2017; Johnson 2014; Msibi 2012; Nzimande 2015).

\section{Subtle heterosexism}

Heterosexist and homophobic language pervaded participants' reports and this was often not direct or intentionally harmful but rather indirect and implicit. We were particularly interested in exploring the manifestation on the micro level of microaggressions that we knew were also happening in different forms on the macro, societal level. Similes of contagion were employed to construct the 'new' phenomenon of 'gayness' and AS believed that homosexuality was spreading through the province of the Western Cape. ${ }^{3}$

Previous years we didn't have so many homosexual children developing and I would like to know why is it so many children homosexual in the Western Cape: why does it happen? Why are they developing into this? Is it television? Is it their parents? Is it things that happens in their houses that focuses them to be in a homosexual relationship? Because I would like to know if there's anything that we can do and how to teach or help them earlier in life not to go into those directions. (AS WF42-US)

3 Cape Town is situated in the Western Cape province of South Africa and is known as the 'gay capital' of both South Africa and of the African continent. 
Of note in AS's construction of homosexuality is the 'us'/'them' binary, alluded to by Carrim (1998) and Carrim and Soudien (1999) in terms of the larger racial divides in South Africa and, in our paper, expressed in terms of sexual identity. AS experienced a 'rise' in homosexuality as an odd phenomenon, the aetiology of which was uncertain and troubling. Her concern about needing to control the emergence of non-normative sexual and gender identities could be an addition to Nadal, Rivera, and Corpus's (2010) taxonomy of LGBT microaggressions. We found that participants throughout the study questioned the origins of homosexuality and, without using such terminology, engaged in the essentialist/social constructionist debate around (non-normative) sexualities, often attributing the origins of homosexuality to pathology, dysfunction and abuse. The stated desire was often to understand where 'it' came from so as to take preventative measures.

The pronoun 'it' was widely used when referring to homosexuality in a way that dehumanised, depersonalised and stripped personhood from participants' conceptualisations of LGBT people (DePalma \& Francis 2014b; Francis 2012; 2017). We were struck by the way in which this linguistic trope was socially sanctioned in relation to sexual and gender minorities but not in relation to other marginalised or minority groups. For example, AW recounted the response of school management to the emergence of 'it' in school:

I've told our headmaster we must do something about it because at first he said we must ignore it. There's not a lot of boys that are open about it at school but there's this gang of lesbian girls which is getting bigger. They are very popular and at first the headmaster said: 'No, let's just not pay a lot of attention to it because then we make it more popular like they want attention and then we focus on them. Let's see if it won't go away by itself'. (AW WF38-UT)

The pathologising intent of participants' discourses was also evident in AW's association of homosexuality with pornography, which constructed same-sex identities in terms of extreme sexualisation and deviance and which reinforced the findings in the literature about the pervasiveness of heterosexism in South African schools (see Bhana 2012; DePalma \& Francis 2014b; Francis 2017; Francis \& Msibi, 2011):

...maybe they're brought up that way by watching pornography with their parents. (AW WF38UT)

PDP, while appearing to use affirming language, talked about the 'other' side of gayness:

What will you do when your only child is gay? Won't you love him? Won't you respect him? Then I give them the other side: not the wrong side of gayness where I'm doing it just for fun or whatever. (PDP WF57-US)

Participant interview data suggest a mix of a somewhat LGBT inclusive and affirming stance with accompanying constructions and (re)constructions of non-normative sexualities. For instance, PDP suggested that being gay was about entertainment - 'having 
fun'- and was also 'wrong'. There was a begrudging acceptance among participants that the 'spread' of homosexuality was something that they struggled to control and which they reluctantly felt the need to deal with. For instance, when asked whether schools should be teaching about homosexuality SL implied that this was not something that was desirable, a response that is consonant with Nadal, Rivera and Corpus's (2010) theoretical taxonomy of LGBT microaggressions:

Now really, whether we like it or not, they are part of our lives. They [learners] will ask: 'How can a man love another man?' And that one is too difficult: how can I answer that? (SL CF40$\mathrm{RS})$

The alterity and abjectness of same-sex desires and bodies was repeatedly constructed and (re)constructed in the discourse of participants. Paradoxically this alterity was constructed as both fully knowable (in terms of aetiology, causation and control) as well as fully uncontrollable and seemingly impossible to understand.

\section{Heteronormativity and pathology}

Participant interview data suggest an omnipresence of heteronormativity and pathologising intent at the macro, system-level discourses and on the micro and individual level. For instance, participants, employing a hetero- and gender-normative lens, tended to conflate sexual orientation, gender identity and sex by presuming that gay boys were transgender or intersex. MS said:

When I was growing up there was this boy, beautiful boy, like a girl so people used to say: 'This boy he has two sexual organs'. They will say: 'Come. Let's go and see'. I don't know the truth, whether a person has those two sexual what-what but I can hear in the news. He has the body of a man but inside he feels like a woman [and] vice versa. (MS AF43-US)

This conflation of non-heterosexuality with transgenderism and intersex conditions is a common theme in the growing body of research on non-normative sexual and gender identities in South Africa, such as among isiZulu speaking South Africans where the problematic isiZulu term of isitabane speaks directly to this ambiguity (see Msibi 2012; Reygan \& Lynette 2014; Sigamoney \& Epprecht 2013). Talking about gay learners BM tells:

....as homosexuals though they will tell you that they have a strong feeling that he's a woman: the woman characteristics dominate him. (BM WF51-US)

The discourse of pathology that pervaded participants' reports continuously constructed and reconstructed non-normative sexual and gender identities as developmentally and psychologically delayed and deviant. Nadal (2008) and Sue (2010) argue that when an individual 'microaggresses' $\mathrm{s} /$ he may not be cognisant of the insulting or derogatory nature of their behaviour and we found that participants were often unaware of the 
demeaning nature of their comments. AW believed that lesbianism resulted from poor relationships with the father figure and from the presence of alcoholism:

The one family that I do know, it's two sisters and they are both lesbian because they don't have a good role model in their father and their mother is also lesbian so it's in their family. They have a father but he's using alcohol and he doesn't show any love to them so they hate men. (AW WF38-UT)

The supposed role of the family in the development of homosexuality was also foregrounded and AS believed that the aetiology of non-heterosexuality lay in the dysfunctional marriages of learners' parents:

Most of them [gay learners] come out of failed marriages: parents who are divorced or had different relationships, multi-relationships with other people and still in the marriage and a lot of those children, a few of them tend to go homosexual. (AS WF42-US)

It is noteworthy that participants are here referring not to teaching of the official curriculum in relation to sexual and gender diversity but rather to their inherited knowledge and prejudices in this area. These are the thoughts, beliefs and attitudes that inform and propel the hidden curriculum which is not taught by the individual teacher alone but perpetuated by the system as a whole (see Britzman 1995; Eisner 1985; Kumashiro 2000; 2002). BM believed that being gay was a phase that could be overcome and that homosexuality was a form of illness or pathology arising from histories of abuse:

It has happened that girls have had therapy and they were molested and they haven't dealt with it and they are now straight. Actually one of our homosexual girls just had a baby and she is not married so she went the other way. You might be going through a phase: there is a boy I know that wondered about his sexuality and we worked through it and he has now got a girlfriend and is happy. (BM WF51-US)

A number of aspects of these reports are noteworthy beyond the pathologising and homophobic intent of these discourses as illustrated in the literature (see Herek 2000; Morrisson \& Morrisson 2003). First, in the absence of any teacher training in the area and of any substantial previous engagement with the topic among participants, there was nevertheless a presumption of knowing. Participants presumed to know about homosexuality, about its origins, the familial and environmental cues that led to 'its' rise and the ways to both control and remove it. Second, participants' reports indicated a voyeuristic approach to the lives of sexual and gender minority learners, whose personal histories, mannerisms and life stories were analysed and parsed so as to individuate cause and effect and develop the most appropriate preventative interventions. Part of this voyeuristic intent was the exoticisation of non-normative sexual and gender identities which is also a form of LGBT microaggression (Nadal, Rivera \& Corpus 2010). 


\section{Discomfort and disapproval of LGBT lives}

Participants were generally overtly or covertly uncomfortable with and disapproving of sexual and gender diversity. This led to distancing on the part of teachers, both from anything in the curriculum that might be sexuality-related as well as from sexual and gender minority learners. Not only were the boundaries of sanctioned knowledge transmission immediately apparent but also the geographies of classrooms where nonnormative sexual and gender identities were policed in a number of ways, not least by means of the hidden curriculum and the discourses constructed in classrooms. PDP said to learners:

I cannot explain why it's the choice of God or what. You believe that it's like this but if you are gay and prefer to be with a boy I must respect it as long as you don't want to make me part of your sexual orientation. (PDP WF57-US)

PDP disapproved of homosexuality, associated 'gayness' with alcohol use, drug use and group sex, and her attitudes were akin to religious condemnation. The 'us'/'them' discourse of binaries captured in this study seemed to mirror racial divides in present day South Africa. In the above narrative, PDP constructs the figure of the overly sexual, impulsive gay 'Other', safely distancing herself as interlocutor from possible contamination and implication in a wantonly hedonistic 'lifestyle'. In PDP's and other reports there was a distinctive and reiterated conjunction of condemnatory clinical and religious discourses that conflated same-sex desire with both sinfulness/evil and with illness/disorder:

Mostly there's a lot of children that are misinformed about gays because there was a time in life, in the world, when gayness I think was a status something: 'I was bored with this flippin' life'. Mostly there was drugs and alcohol and now all these group sex and all those things. I'm telling them about it and I'm showing them there's no good. (PDP WF57-US)

AW felt that teaching bisexuality in particular was time wasted and the issue of 'problem' learners resurfaced:

One or two learners will ask about bisexual people and things like that but I don't waste much time on those topics. Sometimes we have problems because we do have homosexuals at school. (AW WF38-UT)

In keeping with most reports, the 'problem' was considered to be the physical presence of gay and lesbian learners as opposed to the systemic heterosexism in participants' schools. For instance, AS avoided teaching about sexual and gender diversity while CJ's learners laughed, giggled and were disruptive when the subject matter on LGBT was raised. Nonetheless, it seemed apparent that there was a strong learner-driven interest in sexual and gender diversity as evidenced by their questions to participants on this topic. Even then, responses by the participants would suggest that they were largely unable or unwilling to provide information or teaching beyond the usual tropes based 
on cultural norms and unchallenged historical knowledge. For example, JL spoke about social awkwardness, about how uncomfortable it was attempting to negotiate social spaces with gay people, and about the fear of being tainted by association:

How can you relate with such people? Maybe I'm a gentleman and then this is a gentleman and he's a homosexual and then how do I relate with such person because am I not going to be suspected of being one of them? (JL AM43-ST)

This piece of evidence, among other things, suggests that the general crisis in multiculturalism in South Africa (Francis \& Hemson 2007a; 2007b) has taken the form of a particular crisis in relation to the inclusion of LGBT persons, both learners and staff, in the school system. PDP reported that the school principal sent the gay learners to her:

They send the problem children to me. (PDP WF57-US)

\section{'Culture' and religion}

Discourses across the African continent construct non-normative sexual and gender identities as 'unAfrican' and 'Western' (Francis \& Msibi 2011; Reid \& Dirsuweit 2002; Reygan \& Lynette 2014; Sigamoney \& Epprecht 2013). Such perspectives perpetuate heteronormative and gender normative cultures and is a form of LGBT microaggression (see Nadal, Rivera \& Corpus 2010). For example, participants in our study referenced their respective cultural backgrounds as a bulwark against teaching about sexual and gender diversity. EV felt that the teaching of sexual diversity was a threat to her sense of self as an Afrikaner:

I don't want to compromise myself when I'm teaching these things...I mean I'm an Afrikaans, $\mathrm{NGK}^{4}$ girl. My view of that [homosexuality] is very conservative and I think that's probably going to influence the way that I teach the subject. I think LO is supposed to be a subject where you're very open-minded about religion, about sexuality and so forth and it might influence the way that I think about that. It's very difficult to separate one's personal values from one's teaching. (EV WF28-US)

Intersectionality came increasingly to the fore in terms of the tensions between race and class and contradictions in participants' reports became evident. While EV, above, cited white Afrikaner culture as a bulwark against sexual and gender diversity, LP and ES, both white women teaching in township and suburban schools, made similar arguments about 'black culture':

We have problems with lesbianism in our school... and it's a black school. (LP WF47-UT)

$4 \quad$ Dutch Reformed Church 
The 'us'/'them' 'insider'/'outsider' racial divides seem persistent in South Africa (see Carrim 1998; McKinney 2010; 2011; Perumal 2015; Soudien 2007). For instance, when asked what the reaction from African parents was to sexual diversity teaching in the classroom ES said:

As I told you, [in] the black culture [homosexuality is] not acceptable. They don't understand this stuff. (ES WF55-US)

Participants used exegesis, religious discourse and references to the Bible to construct non-normative sexual and gender identities as deviant and immoral. For example, JL talked about the sinfulness of non-normative sexualities in Christian teaching and the social opprobrium that ought to follow:

If you are a boy sleeping with a boy, then you must expect that you'll not be treated accordingly in the society because you are not regarded as a true person. The true Christians have got this perception: we have the man and the woman, the man and the woman, that's all, so if you're a homosexual then there's something wrong with you. Yes, yes. (JL AM43-ST)

Similarly, LT talked about the Christian ethos of her school as an impediment to teaching about homosexuality despite the evident interest of learners:

Another problem is that our school has a strong Christian ethos. It's not something that's written but I think in terms of our school linked to Christianity, it necessarily stops us, my classes, and my lessons to discuss the topic of homosexuality openly and freely even though the kids want to know. The kids do ask questions about homosexuality: there are actually both girls and boys who are just wanting to ask questions on homosexuality and wanting to know. (LT AF28-US)

The religiously sanctioned institutionalisation of heterosexism as a form of social and pedagogical regimentation and control was prevalent throughout participants' reports. When asked how school management would react if they found out LT was going against the religious ethos of the institution and teaching about homosexuality she replied:

I think I'll be a dead cat. I think I'll be a dead cat in all honesty. (LT AF28-US)

Surveillance and the presence of punitive regimes of disciplinary power in participants' schools led to a foreclosure of the possibility of teaching about sexual and gender diversity.

\section{DISCUSSION AND CONCLUSION}

Our study found evidence to suggest that teachers perpetuate heterosexism as well as more subtle and sometimes harder to pin down forms of bias - microaggressions. These found expression in the unreflexive pathologising of non-normative sexual and gender identities as well as in the general discomfort and disapproval around LGBT identities displayed by the teachers that formed part of this study. Pathologising ideology seemed 
palpable during the interviews - sometimes shocking, omnipresent below the surface, inchoate and ready to be voiced.

Participants tended to utilise religious and cultural arguments as a bulwark against engaging with the topic of sexual and gender diversity and the essentialist/constructivist debate pervaded participants' reports as they grappled with the aetiology of 'it' and whether or not gays and lesbians were 'born that way' or became that way through dysfunctional family dynamics and histories of abuse.

Participants seemed to experience discomfort, disapproval and deep suspicion about LGBT identities. The discomfort of participants to engage in LGBT discourse may be explained in part by the fact that they received no formal training in this area and participating in our study required that they position themselves in terms of nonnormative sexual and gender identities. Moreover, it appeared that they had not critically engaged with their own beliefs and attitudes towards sexual and gender minorities which reflected in their producing and reproducing heterosexism or perpetuating the ongoing silencing and invisibility of LGBT learners (Francis 2012; Richardson 2004). Although the participants teaching in the LO subject area were generally aware of broad human rights and social justice issues, there was a lacunae when it came to the inclusion of LGBT people within this broader discourse of inclusion. Nonetheless, LGBT-related 'learning through crisis' (Kumashiro 2000, 31) were amply evident in participants' reports but were not used as an impetus for greater engagement with the topic of sexual and gender diversity or to foster a more inclusive classroom.

A multi-axis understanding of the phenomenon is necessary in terms of engaging the barriers that teachers face in teaching in an inclusive manner. While a macro, systemslevel understanding of oppression is necessary, such as provided by Kumashiro, we also know that power, privilege and oppression work on an individual level. It is here that the concept of microaggressions becomes useful in understanding the manner in which oppression plays out at the individual, psychological and intrapsychic levels, thereby opening up opportunities for teacher training that works on all these levels. From a social justice lens, there was evidence to suggest a lack of education for LGBT learners in participants' classrooms who reported that heterosexist bullying generally went unchecked. Education about the Other tended to occur through the hidden curriculum with little apparent LGBT-affirming teaching taking place. When participants did teach about LGBT identities they tended to do so in a particularly heteronormative and pathologising manner. In terms of education that is critical of privileging and Othering there was little reflexivity among participants or amongst learners as to the ways in which the privileging of hetero-/gender normativity takes place in society and in the classroom. It appears that participants in our study did not intend to take any discernible form of action to bring about progressive change in schools and society as this relates to sexual and gender minorities. Participants likely were unable to adequately respond to the learner-driven desire to know about sexual and gender diversity. In addition, they may not have been in a position to reply in an informed and pedagogically coherent 
manner. This might be explained by the fact that unconscious and sometimes conscious microaggressions perpetuated by participants reflected not only their own unelaborated biases against an historically invisible group but also the discourses of heterosexism that are inextricably tied to racism and sexism. Sexual and gender minorities are a protected class in the South African Constitution and in educational policy, although the experiences of participants as reported in this study indicate a failure to transform attitudes in this area.

We found that a number of key factors led to the emergence of LGBT microaggressions. These included a lack of pre-service and in-service teacher education in the area, societal norms that go unchallenged, and a lack of self-reflection among teachers about the issues. Our findings indicate the need for further study so as to elucidate additional factors that lead to the emergence of LGBT microaggressions.

Our study on teachers and LGBT microaggressions has implications for curriculum, policy and teacher education and, in bringing our article a close, we list these. First, the findings from the study have implications in terms of the curriculum, and specifically the hidden curriculum, regarding sexual and gender minority identities. For instance, Francis (2012; 2017), Msibi (2012) and Potgieter and Reygan (2012) have proposed an inclusive curriculum to engage with the silences, invisibility and problematic constructions and representations of LGBT identities in South African schools and in textbooks. Given the possibility of a LGBT inclusive curriculum, we posit that the topic of sexual and gender diversity ought not to be confined to the LO subject area but rather taught across subject areas. Following Kumashiro (2000; 2002), we also suggest that curriculum development in this area avoid simply engaging in education about the Other. Rather, curriculum advances in this area need to embrace the full gamut of Kumashiro's framework that includes education for the Other, about the Other, education that critiques privileging and Othering and, most importantly, education that changes learners, teachers, the learning process and society as a whole. On the basis of the findings of the present study, we advocate for the development of competent and informed approaches to education that 'trouble' knowledge of and about the Other. The knowledge base should be inclusive without both privileging and Othering sexually diverse learners and educators. Second, the study has implications in terms of policy. We conceptualise 'policy' as operating on all levels and not just at national or provincial level and see LGBT microaggressions as having relevance for policy at all levels - in departments of education, communities, schools and classrooms - in sociologically and context-dependent situations. We see LGBT microaggressions as a form of bullying, and of heterosexist bullying in particular, and therefore their presence is something that education policy makers need to take cognisance of in terms of developing and rolling out anti-bullying and anti-heterosexist bullying initiatives and campaigns in South Africa. Third, the findings from the study have implications for teacher education, given the need to make LGBT training modules available to all pre- and in-service teachers across South Africa. 


\begin{tabular}{|c|c|c|c|c|c|c|c|c|c|c|}
\hline 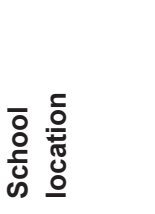 & 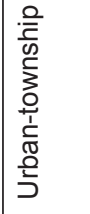 & 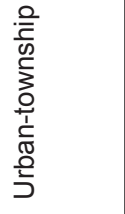 & 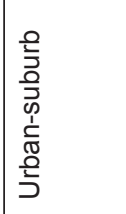 & 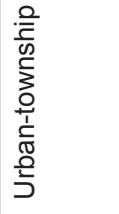 & 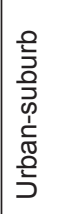 & 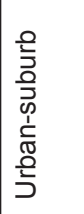 & 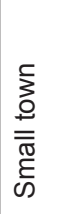 & 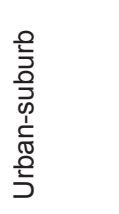 & 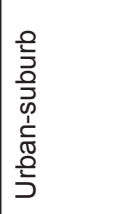 & 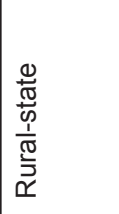 \\
\hline 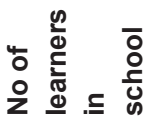 & $\bar{ু}$ & 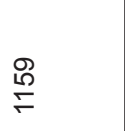 & 只 & ஜ్ర & $\underset{\infty}{\stackrel{N}{N}}$ & గ్రి & 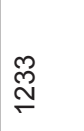 & $\stackrel{\text { N }}{\underset{N}{N}}$ & \&̊ㅁㅁ & 로 \\
\hline 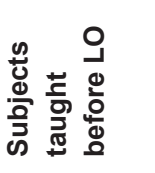 & 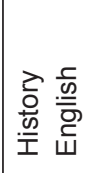 & 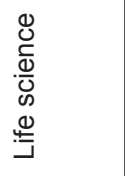 & 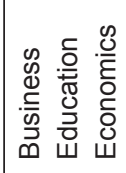 & 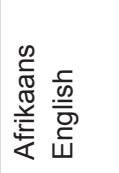 & 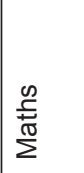 & $\begin{array}{l}\text { D } \\
\stackrel{5}{ \pm} \\
\sum \\
\sum\end{array}$ & 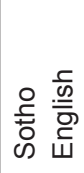 & 오 & 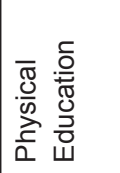 & 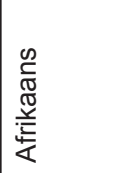 \\
\hline 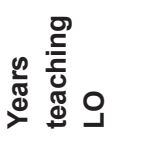 & 0 & $\stackrel{\infty}{\leftarrow}$ & 10 & $\sigma$ & $\sim$ & $\sim$ & $m$ & $\sigma$ & $m$ & $\stackrel{m}{\circ}$ \\
\hline 赵 & ㅇ & $\stackrel{\llcorner}{\sim}$ & $\stackrel{2}{N}$ & $\stackrel{0}{\circ}$ & $m$ & 0 & $\stackrel{6}{\sim}$ & $\stackrel{N}{\leftarrow}$ & 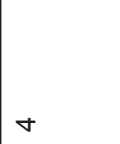 & $\stackrel{m}{\longrightarrow}$ \\
\hline 总 & 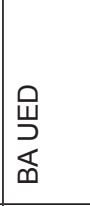 & 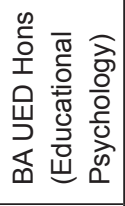 & 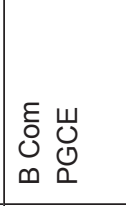 & 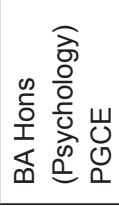 & $\begin{array}{ll} & \text { U } \\
0 & 0 \\
\infty & 0 \\
\varnothing & \\
\end{array}$ & $\begin{aligned} & \text { U } \\
& 0 \\
& \varnothing 0 \\
& 0\end{aligned}$ & $\begin{array}{l}\text { 饪 } \\
\text { ๓ }\end{array}$ & 岂 & 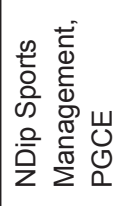 & 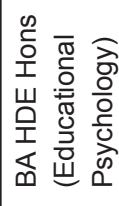 \\
\hline$\frac{}{\frac{0}{0}}$ & 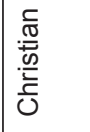 & 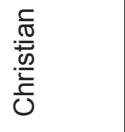 & 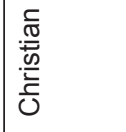 & 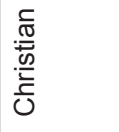 & 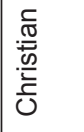 & 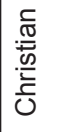 & 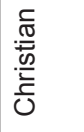 & 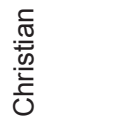 & 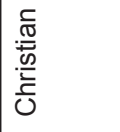 & 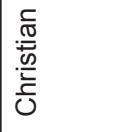 \\
\hline 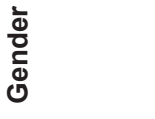 & $\Sigma$ & レ & ४ & レ & $\Sigma$ & ए & $\Sigma$ & レ & 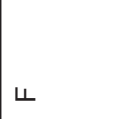 & ४ \\
\hline 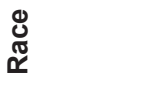 & $\varangle$ & 3 & 3 & 3 & 3 & 3 & $\varangle$ & $\varangle$ & $\varangle$ & 0 \\
\hline$\stackrel{0}{8}$ & $\stackrel{\text { L }}{q}$ & 守 & in & $\stackrel{\infty}{\infty}$ & $\hat{\sim}$ & $\stackrel{\sim}{\sim}$ & ঙ̊ & $\stackrel{\mathscr{\sim}}{+}$ & $\stackrel{\sim}{\sim}$ & 웅 \\
\hline 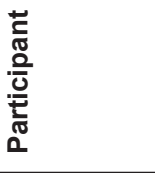 & $\sum_{\Sigma}$ & 回 & $\sum_{\infty}$ & 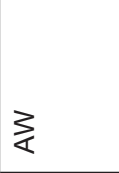 & $\stackrel{0}{0}$ & 学 & $\Rightarrow$ & $\sum^{\infty}$ & 士 & $\dot{\omega}$ \\
\hline 운 & - & $\sim$ & $m$ & $\nabla$ & م & 0 & $\wedge$ & $\infty$ & $\infty$ & 으 \\
\hline
\end{tabular}




\begin{tabular}{|c|c|c|c|c|c|c|c|}
\hline 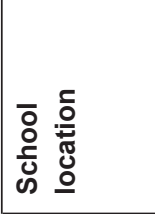 & 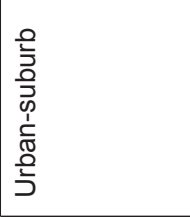 & 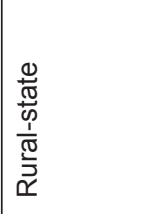 & 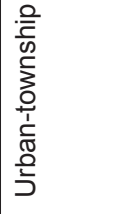 & 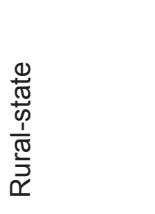 & 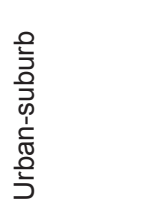 & 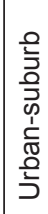 & 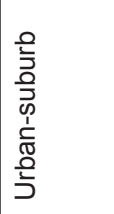 \\
\hline 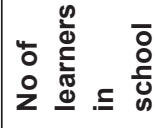 & $\stackrel{\text { N }}{\stackrel{\text { }}{*}}$ & 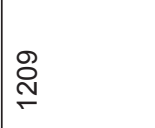 & 同 & $\stackrel{\text { ิ }}{\sim}$ & $\begin{array}{l}\infty \\
\infty \\
\infty\end{array}$ & \begin{tabular}{|l}
$\infty$ \\
$\infty$ \\
$\infty$
\end{tabular} & 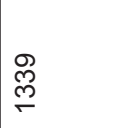 \\
\hline 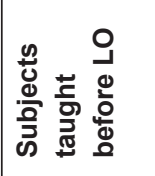 & 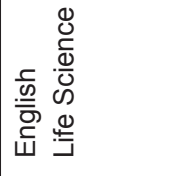 & 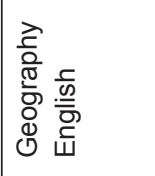 & 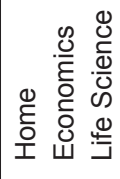 & 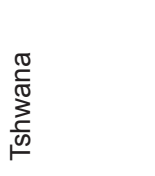 & 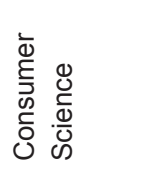 & 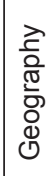 & 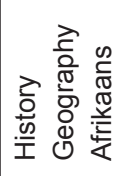 \\
\hline 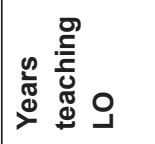 & $\sigma$ & 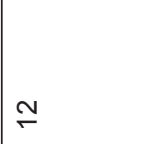 & $\sim$ & $\sigma$ & 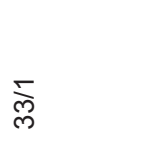 & 0 & $\underset{\nabla}{ }$ \\
\hline 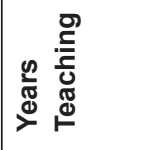 & $\stackrel{\sim}{\sim}$ & $\stackrel{9}{\longrightarrow}$ & $\wedge$ & $\stackrel{m}{\sim}$ & m & ల్ల & 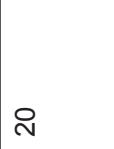 \\
\hline 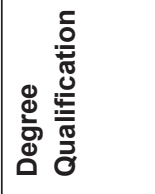 & 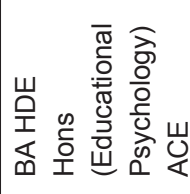 & 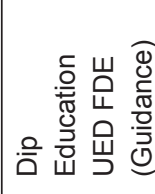 & 匹 堊 & 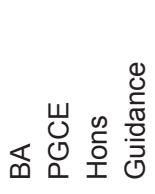 & 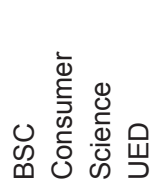 & 岂 & 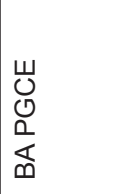 \\
\hline$\frac{}{.0}$ & 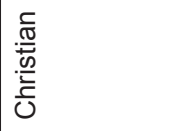 & 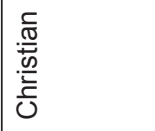 & 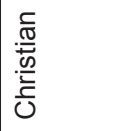 & 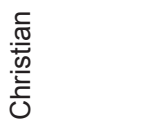 & 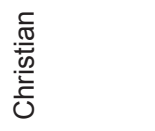 & 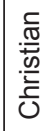 & 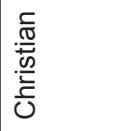 \\
\hline 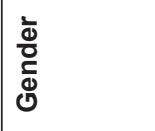 & $\Sigma$ & ४ & レ & ४ & ᄂ & $\Sigma$ & ᄂ \\
\hline 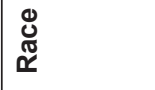 & $\varangle$ & $\varangle$ & 3 & $\varangle$ & 3 & 3 & 3 \\
\hline 通 & เి & $\stackrel{m}{+}$ & மొ & ஓి & in & เి & م \\
\hline 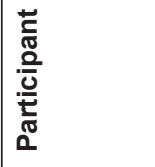 & $\sum_{x}$ & $\frac{0}{\infty}$ & 号 & $\sum_{\longleftarrow}$ & 吕 & z & 出 \\
\hline z & $\mp$ & $\simeq$ & $\stackrel{m}{\square}$ & $\underset{\sim}{\nabla}$ & $\stackrel{10}{2}$ & $\stackrel{\varphi}{\circ}$ & $\approx$ \\
\hline
\end{tabular}




\begin{tabular}{|c|c|c|c|c|c|c|c|c|}
\hline 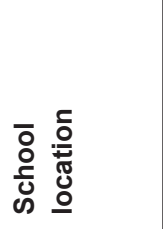 & 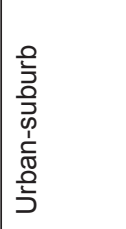 & 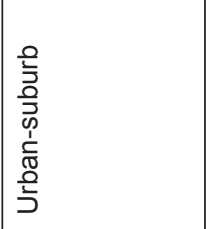 & 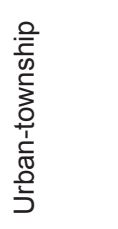 & \begin{tabular}{|l}
$\frac{0}{\bar{E}}$ \\
$\frac{0}{0}$ \\
$\frac{2}{3}$ \\
$\frac{0}{0}$ \\
$\frac{1}{1}$ \\
$\frac{0}{0}$ \\
$\frac{0}{5}$
\end{tabular} & $\begin{array}{l}\frac{0}{\bar{Z}} \\
\frac{0}{0} \\
\frac{2}{2} \\
\frac{0}{0} \\
\frac{0}{1} \\
\frac{0}{0} \\
\frac{0}{5}\end{array}$ & 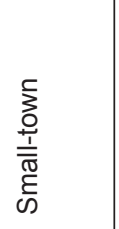 & 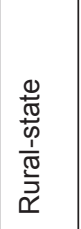 & 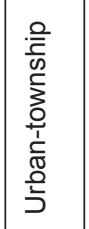 \\
\hline 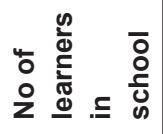 & 悤 & $\stackrel{\varnothing}{\infty}$ & $\stackrel{\infty}{\stackrel{\infty}{\leftarrow}}$ & $\stackrel{\infty}{\stackrel{\infty}{\rightleftharpoons}}$ & $\stackrel{\infty}{\stackrel{\infty}{\leftarrow}}$ & $\begin{array}{l}\mathscr{0} \\
\stackrel{\infty}{\infty}\end{array}$ & 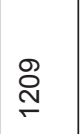 & 㑭 \\
\hline 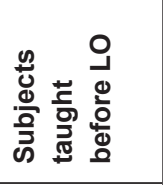 & 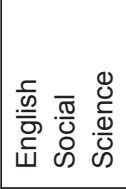 & 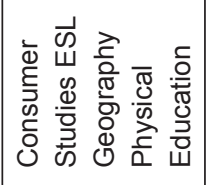 & 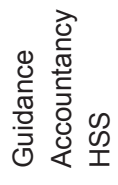 & 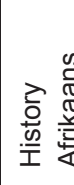 & 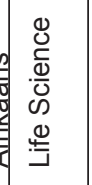 & 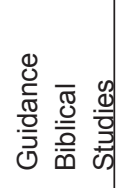 & 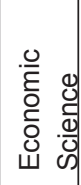 & 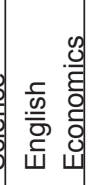 \\
\hline 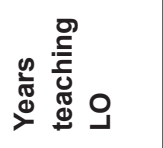 & 0 & 우 & م & $m$ & - & $\stackrel{\varphi}{\circ}$ & $\sim$ & م \\
\hline 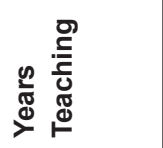 & $\cong$ & $\bar{N}$ & $\stackrel{9}{-}$ & $m$ & - & ి్ల & $m$ & N \\
\hline 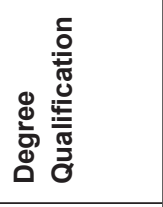 & 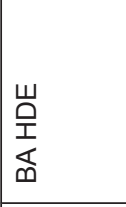 & 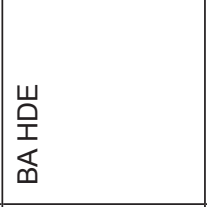 & 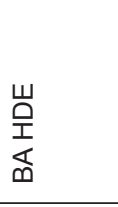 & 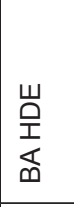 & 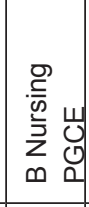 & 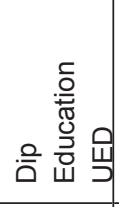 & 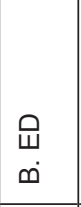 & 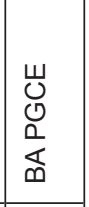 \\
\hline 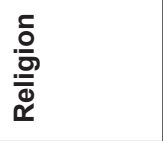 & 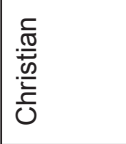 & 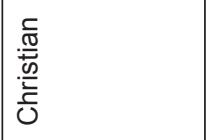 & 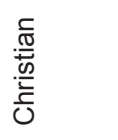 & 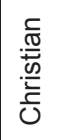 & 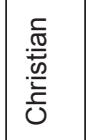 & 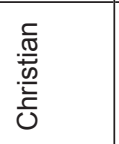 & 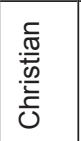 & 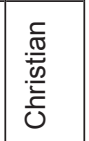 \\
\hline 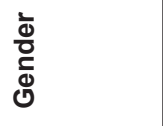 & $\sqcup$ & ᄂ & $\Sigma$ & レ & ч & $\Sigma$ & $\Sigma$ & $\Sigma$ \\
\hline 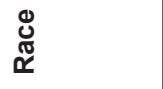 & 3 & 3 & $\ll$ & 0 & 0 & $\varangle$ & $\varangle$ & $\ll$ \\
\hline 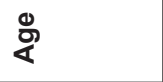 & Д్ల & F & $\stackrel{\infty}{\sim}$ & $\stackrel{\leftrightarrow}{\sim}$ & $\stackrel{\mathscr{P}}{+}$ & in & 尺 & @ \\
\hline 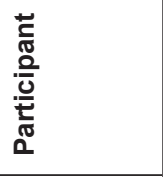 & $\stackrel{0}{\Sigma}$ & 里 & O) & 3 & $\stackrel{\infty}{\gtrless}$ & $\stackrel{Y}{\vdash}$ & $\sum$ & $\sum$ \\
\hline zo & $\stackrel{\infty}{\sim}$ & $\stackrel{9}{\circ}$ & i & $\bar{N}$ & N & $\stackrel{\sim}{\sim}$ & $\stackrel{\sim}{ }$ & $\stackrel{2}{\sim}$ \\
\hline
\end{tabular}




\section{REFERENCES}

Ahmed, N., A. Flisher, C. Mathews, W. Mukoma and S. Jansen. 2009. HIV education in South African schools: The dilemma and conflicts of educators. Scandinavian Journal of Public Health 37(2): $48-54$.

Baxen, J. 2008. Teacher identity and the challenge of teaching about, and within, the context of HIV/ AIDS. In Gender, sexuality and development. Edited by M. Dunne, 171-183. Rotterdam: Sense Publishers.

Bennett, J. and V. Reddy. 2015. 'African positionings': South African relationships with continental questions of lgbti justice and rights. Agenda 29(1): 10-23. https://doi.org/10.1080/10130950.2 015.1015829

Bhana, D. 2012. Understanding and addressing homophobia in schools: A view from teachers. South African Journal of Education 32(3): 307-318.

Blumenfeld, W. 2000. How homophobia hurts everyone. In Readings for diversity and social justice. Edited by M. Adams. New York: Routledge.

Britzman, D. 1995. Is there a queer pedagogy? Or stop thinking straight. Educational Theory 45(2): 151-165.

Butler, A. and G. Astbury. 2008. The use of defence mechanisms as precursors to coming out in postapartheid South Africa: A gay and lesbian youth perspective. Journal of Homosexuality 55(2): 223-244. https://doi.org/10.1080/00918360802129485

Carrim, N. 1998. Anti-racism and the 'new' South African educational order. Cambridge Journal of Education 28(3): 301-320.

Carrim, N. and C. Soudien. 1999. Critical antiracism in South Africa. In Critical multiculturalism: Rethinking multicultural and antiracist education. Edited by S. May, 163-164. New York: Routledge.

Denzin, N.K. 1989. Interpretative interactionism. Newbury Park: Sage Publications.

DePalma, R. and D. Francis. 2014a. Silence, nostalgia, violence, poverty...: What does 'culture' mean for South African sexuality educators? Culture, Health \& Sexuality 16(5): 547-561. https://doi. org/10.1080/13691058.2014.891050

DePalma, R. and D. Francis. 2014b. South African Life Orientation teachers: (Not) teaching about sexuality diversity. Journal of Homosexuality 61(12): 1687-1711. https://doi.org/10.1080/009 18369.2014.951256

DePalma, R. and D. Francis. 2014c. The gendered nature of South African teachers' discourse on sex education. Health Education Research 29(4): 624-632. https://doi.org/10.1093/her/cyt117

Eisner, E. 1985. The educational imagination: On the design and evaluation of school programs. 2nd edition. New York: MacMillan Publishing.

Francis, D. 2010. Sexuality education in South Africa: Three essential questions. International Journal of Educational Development 30(3): 314-319. https://doi.org/10.1016/j.ijedudev.2009.12.003

Francis, D. 2012. Teacher positioning on the teaching of sexual diversity in South African schools. Culture, Health \& Sexuality 14(6): 597-611. https://doi.org/10.1080/13691058.2012.674558

Francis, D. 2013. Sexuality education in South Africa: Whose values are we teaching? Canadian Journal of Human Sexuality 22(2): 69-76. 
Francis, D. 2016a. 'I felt confused; I felt uncomfortable...my hair stood on ends': Understanding how teachers negotiate comfort zones, learning edges and triggers in the teaching of sexuality education in South Africa. In Global perspectives and key debates in sex and relationships education: Addressing issues of gender, sexuality, plurality and power. Edited by V. Sundaram and H. Sauntson, 130-145. London: Palgrave Macmillan. http://dx.doi.org/10.1057/9781137500229_9

Francis, D. 2017. Troubling the teaching and learning of gender and sexuality diversity in South African education. New York: Palgrave Macmillan.

Francis, D. and R. DePalma. 2013. Teacher perspectives on abstinence and safe sex education in South Africa. Sex Education 14(1): 81-94. https://doi.org/10.1080/14681811.2013.833091

Francis, D. and R. DePalma. 2015. 'You need to have some guts to teach': Teacher preparation and characteristics for the teaching of sexuality and HIV/AIDS education in South African schools. SAHARA-J: Journal of Social Aspects of HIV/AIDS 12(1): 30-38.

Francis, D. and C. Hemson. 2007a. Multiculturalism in South Africa: Education in the shadow of the rainbow. Journal of Educational Studies 6: 39-51.

Francis, D. and C. Hemson. 2007b. Rainbow's end: Consciousness and enactment in social justice education. Perspectives in Education 25: 99-112.

Francis, D. and T. Msibi. 2011. Teaching about heterosexism: Challenging homophobia in South Africa. Journal of LGBT Youth 8(2): 157-173. https://doi.org/10.1080/19361653.2011.553713

Francis, D. \& F. Reygan. 2016. Relationships, intimacy and desire in the lives of lesbian, gay and bisexual youth in South Africa. South African Review of Sociology 47(3): 65-84. http://doi: $10.1080 / 21528586.2016 .1163290$

Free State's Regional Steering Committee. 2010. Free State, self-evaluation report. OECD Reviews of higher education in regional and city development. IMH. Retrieved from: http://www.oecd. org/edu/imhe/regionaldevelopment (accessed 28 January 2016).

Griffin, P., K. D'errico, B. Harro and T. Schiff. 2007. Heterosexism curriculum design. In Teaching for diversity and social justice. Edited by M. Adams, L.A. Bell and P. Griffin. New York: Routledge.

Hardiman, R., B. Jackson and P. Griffin. 2007. Conceptual framework for social justice education. In Teaching for diversity and social justice: A source book. Edited by M. Adams, L. Bell and P. Griffin, 35-66. New York: Routledge Taylor and Francis Group.

Helleve, A., A. Flisher, H. Onya, W. Mukoma and K. Klepp. 2009. South African teachers' reflections on the impact of culture on their teaching of sexuality and HIV/AIDS. Culture Health \& Sexuality 11: 189-204.

Herek, G. 2000. The psychology of sexual prejudice. Current Directions in Psychological Science 9(1): 19-22. https://doi.org/10.1111/1467-8721.00051

Hill, D. and B. Willoughby. 2005. The development and validation of the genderism and transphobia scale. Sex Roles 53(7): 531-544. https://doi.org/10.1007/s11199-005-7140-x

Johnson, B. 2014. The need to prepare future teachers to understand and combat homophobia in schools. South African Journal of Higher Education 28(4): 1249-1268.

Kowen, D. and J. Davis. 2006. Opaque young lives: Experiences of lesbian youth. Agenda 20(67): 80-92. https://doi.org/10.1080/10130950.2006.9674701

Kumashiro, K. 2000. Toward a theory of anti-oppressive education. Review of Educational Research 70: $25-53$. 
Kumashiro, K. 2002. Troubling education: Queer activism and anti-oppressive pedagogy. New York: Routledge Falmer.

Kumashiro, K., S. Baber, E. Richardson, C. Ricker-Wilson and P. Wong. 2004. Preparing teachers for anti-oppressive education: International movements. Teaching Education 15: 257-275.

Lynn, M. 2002. Critical race theory and the perspectives of black men teachers in the Los Angeles public schools. Equity \& Excellence in Education 35(2): 119-130. https://doi.org/10.1080/713845287

Marx, J. 2014. Negotiating homosexual in/visibility. In Reclaiming Afrikan: Queer perspectives on sexual and gender identities. Edited by Z. Matabeni, 33-35. Johannesburg: Modjaji books.

Matabeni, Z. 2011. Exploring black lesbian sexualities and identities in Johannesburg. Doctoral dissertation. University of the Witwatersrand, Johannesburg.

Matabeni, Z. 2014. How not to write about queer South Africa. In Reclaiming Afrikan: Queer perspectives on sexual and gender identities. Edited by Z. Matabeni, 61-63. Johannesburg: Modjaji books.

Mathews, C., H. Boon, A.J. Flisher and H.P. Schaalma. 2007. Factors associated with teachers' implementation of HIV/AIDS education in secondary schools in Cape Town, South Africa. AIDS Care 18(4): 388-397. https://doi.org/10.1080/09540120500498203

McArthur, T. 2015. Homophobic violence in a Northern Cape school: Learners confront the issue. Agenda 29(3): 53-59. https://doi.org/10.1080/10130950.2015.1056587

McKinney, C. 2010. Schooling in black and white: Assimilationist discourses and subversive identity performances in a desegregated South African girls' school. Race, Ethnicity \& Education 13(2): 191-207.

McKinney, C. 2011. Asymmetrical relations of knowing: Pedagogy, discourse and identity in a de(re) segregated girls' school. Journal of Education 51: 1-23.

Merriam, S.B. 1998. Qualitative research and case study application in education. San Francisco: JosseyBass Publishers.

Minikel-Lacocque, J. 2013. Racism, college, and the power of words: Racial microaggressions reconsidered. American Educational Research Journal 50(3): 432-465. https://doi. org/10.3102/0002831212468048

Morrisson, M. and T. Morrisson. 2003. Development and validation of a scale measuring modern prejudice toward gay men and lesbian women. Journal of Homosexuality 43(2): 15-37. https:// doi.org/10.1300/J082v43n02_02

Msibi, T. 2012. 'I'm used to it now': Experiences of homophobia among queer youth in South African township schools. Gender and Education 24(5): 515-533. https://doi.org/10.1080/09540253.2 011.645021

Nadal, K.L. 2008. Preventing racial, ethnic, gender, sexual minority, disability, and religious microaggressions: Recommendations for promoting positive mental health. Prevention in Counseling Psychology: Theory, Research, Practice and Training 2(2): 22-27.

Nadal, K.L., M.-A. Issa, J. Leon, V. Meterko, M. Wideman and Y. Wong. 2011. Sexual Orientation Microaggressions: 'Death by a thousand cuts' for lesbian, gay, and bisexual youth. Journal of LGBT Youth 8(3): 234-259. https://doi.org/10.1080/19361653.2011.584204

Nadal, K.L., D. Rivera and M. Corpus. 2010. Sexual orientation and transgender microaggressions in everyday life: Experiences of lesbians, gays, bisexuals, and transgender individuals. In 
Microaggressions and marginality: Manifestation, dynamics, and impact. Edtied by D. Sue. New York: Wiley \& Sons.

Nzimande, N. 2015. Teaching pre-service teachers about LGBTI issues: Transforming the self. Agenda 29(1): 74-80. https://doi.org/10.1080/10130950.2015.1010299

Perumal, J. 2015. Responding with hospitality: Refugee children in the South African education system. Education as Change 19(3): 65-90. https://doi.org/10.1080/16823206.2015.1085622

Pharr, S. 1998. Homophobia: A weapon of sexism. Inverness: Chardon Press.

Pheterson, G. 1986. Alliances between women: Overcoming internalized oppression and internalized domination. Signs 12(1): 146-160.

Posel, D. 2004. Getting the nation talking about sex: Reflections on the discursive constitution of sexuality in South Africa since 1994. Agenda 62: 53-63.

Potgieter, C. and F. Reygan. 2012. Lesbian, gay and bisexual citizenship: A case study as represented in a sample of South African Life Orientation textbooks. Perspectives in Education 30(4): 39-51.

Reid, G. 2003. 'It is just a fashion!' Linking Homosexuality and 'Modernity' in South Africa. Etnofoor 16(2): 7-25.

Reid, G. and T. Dirsuweit. 2002. Understanding systemic violence: Homophobic attacks in Johannesburg and its surrounds. Urban Forum 13(3): 99-126. https://doi.org/10.1007/s12132002-0010-5

Reygan, F. and D. Francis. 2015. Emotions and pedagogies of discomfort: Teachers' responses to sexual and gender diversity in the Free State, South Africa. Education as Change 19(1): 101119. https://doi.org/10.1080/16823206.2014.943259

Reygan, F. and A. Lynette. 2014. Heteronormativity, homophobia and 'culture' arguments in KwaZulu-Natal, South Africa. Sexualities 17(5/6): 707-723.

Richardson, E. 2004. 'A ripple in the pond': Challenging homophobia in a teacher education course. Education as Change 8: 146-163.

Sigamoney, V. and M. Epprecht. 2013. Meanings of homosexuality, same-sex sexuality, and Africanness in two South African townships: An evidence-based approach for rethinking samesex prejudice. African Studies Review 56(2): 83-107. https://doi.org/10.1017/asr.2013.43

Solórzano, D., M. Ceja and T. Yosso. 2000. Critical race theory, racial microaggressions, and campus racial climate: The experiences of African American college students. The Journal of Negro Education 69(1/2): 60-73.

Solórzano, D. and T. Yosso. 2002. A critical race counterstory of race, racism, and affirmative action. Equity \& Excellence in Education 35(2): 155-168. https://doi.org/10.1080/713845284

Soudien, C. 2007. The asymmetries of contact: An assessment of 30 years of school integration in South Africa. Race, Ethnicity \& Education 10(4): 439-456.

Sue, D. 2010. Microaggressions in everyday life: Race, gender, and sexual orientation. New York: Wiley.

Sue, D. and C. Capodilupo. 2008. Racial, gender, and sexual orientation microaggressions: Implications for counseling and psychotherapy. In Counseling the culturally diverse: Theory and practice. Edited by D. Sue. New York: Wiley. 
Thani, Q. 2016. Towards gender and sexuality diversity in South African Schools: Exploring the policy development process in the Department of Basic Education. Doctoral dissertation. University of the Free State, Bloemfontein.

Unterhalter, E., D. Epstein, R. Morrell and R. Moletsane. 2004. Be yourself: Class, race, gender and sexuality in South African schoolchildren's accounts of social relations. Pedagogy, Culture \& Society 12(1): 53-72. https://doi.org/10.1080/14681360400200189

Walls, N. 2008. Toward a multidimensional understanding of heterosexism: The changing nature of prejudice. Journal of Homosexuality 55(1): 20-70. https://doi.org/10.1080/00918360802129287

Wood, L. and L.A. Rolleri. 2014. Designing an effective sexuality education curriculum for schools: Lessons gleaned from the South(ern) African literature. Sex Education 14(5): 525-542. https:// doi.org/10.1080/14681811.2014.918540

Yosso, T. 2002. Toward a critical race curriculum. Equity \& Excellence in Education 35(2): 93-107. https://doi.org/10.1080/713845283

Yosso, T. 2005. Whose culture has capital? A critical race theory discussion of community cultural wealth. Race, Ethnicity and Education 8(1): 69-91.

Young, I.M. 2000. Five faces of oppression. In Readings for diversity and social justice. Edited by M. Adams. New York: Routledge. 